\title{
The Effectivity of Association Picture Media Application Toward the Katakana Letter Reading Comprehension of Grade Ten Students of SMK (Vocational School) Manajemen Jakarta School Year 2010/2011
}

\author{
Restoe Ningroem
}

Faculty of Pedagogue and Education, University of Muhammadiyah Prof. DR. HAMKA, Indonesia

Copyright (C) 2015 by authors, all rights reserved. Authors agree that this article remains permanently open access under the terms of the Creative Commons Attribution License 4.0 International License

\begin{abstract}
The purpose of this research is to acknowledge the effectivity of using association picture media toward the students' katakana letter reading comprehension. The hypothesis proposed was the ability of students' katana letter reading skill that apply association picture is more effective to compare if no such media is applied. The research was conducted to grade ten students of SMK Manajemen Jakarta school year 2010/2011. The research used experiment quasi method. The sample was taken from 50 students which consisted of 25 students as experimental class and 25 students as control class. The data collection technique used an instrument of katakana alphabet reading comprehension test. The requirement test of data analysis used in this research were Liliefors-test for normality and Fisher-test for homogeneity, it was revealed that the class was normal and homogenous. Hypothesis' assessment used t-test which showed $\mathrm{t}$ count $=7,67 \geq 1,67=\mathrm{t}$ table that rejected $\mathrm{H} 0$. It is concluded from the research that association picture media is effective to increase student's comprehension in reading katakana letter.
\end{abstract}

Keywords Learning Media, Association Picture, Reading Katakana

\section{Introduction}

Indonesia has had bilateral cooperation with other countries for a long time, this include Japan. The initial diplomatic treaty between Japan and Indonesia was signed by both foreign minister Aiichiro Fujiyama and Subandrio in Jakarta, 20 January 1958. This treaty serves as everlasting stele that ended the war wedged for thirteen years between the two nations (Utomo, 2007).

In engaging cooperation with other country, it is necessary to comprehend the language, because it is the sound symbol system that articulated (produced by speech device) which is used by community member to cooperate, interact, and self recognition (TPKB, 2005)

One of the important evidences of language serves in engaging cooperation with Japan has been showed by the accommodation of Japanese (language) curriculum in middle schools in Indonesia. Acquiring skill in Japanese is a basic step and open access for our people to study, get knowledge, understand their culture, and have employment in Japan, a modern and developed country. A country that has rich natural resources, various culture, and positive values that deserve to learn from.

In order to have language skill in Japanese, it is necessary to study literatures and researches of Japanese first hand. One of the components of Japanese writing system is Katakana letter. Katakana is used in writing words that comes from foreign language that has been adapted to Japanese (gaigaigo).

According to Iwabuchi[1], the writing of Katakana tends to be easier than Hiragama. Character of the letter is rigid and easy to write, not swiftly or wavy like hiragana letter. Katakana letter is formed from straight lines and scribble (Sudjiabto \& Dahidi, 2007).

In reality, students find it difficult to memorize Katakana compare to Hiragama because Hiragama appears more in the text book. As Katakana letter functions mentioned above, Katakana letters also important to be mastered (Izayoi, 2007).

Students' obstacle in learning Katakana is revealed to be psychologist one, such as: interest, attitude, confidence, and intelligence. Students who love the subject, topics and teacher will have different learning outcome from those who react oppositely. Inattentiveness, caused by less attractive teaching approach and method, resulting in monotonous delivery triggers boringness among students (Basyiruddin, 2002). 
One of the efforts to overcome the issue is to use media in teaching Katakana letter. According to Hamalik[2], using media in learning process can stimulate new will and interest, arouse motivation and eagerness in learning, and even affects psychologically to students. It can also ease students to comprehension, presents data interestingly and reliably, interpretates data and information easily (Rohani, 1997).

One of teaching media that eases students in learning Katakana is association media pictures, the benefit of such media can deliver message, idea, etc. that involves little verbal languages but, leaves deeper impression (Arsyad, 2003).

With association picture media, learners will have long term memorization of Katakana letters because association makes words easy to store in the memory and to recall if needed since they already accustomed to the words (Sameto, 2003). This research is conducted to find out how successful applying association pictures in learning Katakana letters are. The writer conducted research to the basic level students of Japanese class.

\section{Library Review}

\section{Learning Media}

Association of Education and Communication Technology (AECT) in USA identifies media as all forms and channels which is used to deliver message or information (Arshad, 2005). Gerlach and Ely[3] give definition of media broadly and narrowly. Broadly, it means every individual, material, or event that gives student opportunity to gain knowledge, skill, and manner. From that view, we understand that media doesn't simply mean things, it can also means human and learning event. Teacher, text book, school environment can be the media. While narrowly, media is non-personal media that teacher use as people in charge of the learning process to achieve goal. That way media tends to be looked as graphical tools, photograph, or electronic tools to grasp, reshapes visual or verbal information (Roshidi, 2009).

Teaching media can be interpreted in various ways. Whatever the limit given to it, there are similarities. Among them is, everything that applicable to deliver message from teacher to learner that allows learner to accept knowledge, skill and manner, stimulate brain as well, feeling, attention, and interest of learner somehow that the learning process occurs.

Generally, educational media has functions to make clear the message delivery in order to avoid much verbal, overcome space limit, time and senses, avoids students to be passive, and to set the same perception.

According to Hamalik[3] educational media is something that can be digested by the senses, shape and things which is visual and audio, used as means of communication in learning process, as an aid in learning process and related with teaching method.

Picture is a crucial visual and available everywhere. Crucial because it can replace verbal words, concretes the abstract. Pictures enable people grasp the idea or information contained clearly, vividly than words can say (Munadi, 2007). As the Chinese saying, pictures speak more than a hundred words (Adiman, 2009).

By noticing the importance of enhancing students Katakana reading comprehension and the benefit of association picture media which looses troublesome for students to memorize the shape of Katakana letters in a long period. Therefore, it is assumed that association picture media is suitable and effective to be applied in the learning process.

\section{Association}

Association is relating one event to another event, between someone and other people which considers as a related series and interconnected to each other.

In learning foreign language, we must develop association as a mean that allows us memorize words easily and brings full picture and any circumstances that embedded in that words (Sameto, 2003).

The ability to associate in learning foreign language needs to be developed according to particular tastes. Association is available to be developed for all life aspects and circumstance that related to our life (Sameto, 2003).

Memorization in conventional way is by applying left brain hemisphere by memorizing and repeating materials, while association is done by applying right brain hemisphere to memorize symbols or pictures which is easier and quicker to absorb.

If we memorize conventionally, then the memory will go to the left brain which will last in short term, while memorizing by association, memory will go to the right hemisphere that lasts for a long term.

From descriptions and benefits of association elaborated above. It can be concluded that the association picture media discussed in this research is pictures that serves as noun or verb that resembles Katakana letter as a series of meaning that interconnected to each other to smoothen long term memorization of Katakana letter shapes.

\section{Reading Comprehension}

Anderson [4] (Syamri, 2011) defines reading as uttering written language symbols. While A.S. Broto[5] (Syamri, 2011) states that reading is uttering sound symbol.

There are three main branches in learning to read, they are as follows:

\section{Bottom-Up Theory}

According to this theory, reading starts by knowing letter of a word, knowing words from a sentence and knowing sentence from a reading text. One of reading model approaches that use this theory is Gough Model.

\section{Top Down Theory}

To be able to read, one must have knowledge about text he/she will read, if not then, he/she will not be able to read a text or writing. To understand a text or writing, one must master semantics, syntax, and graph phonics. 
3. Interactive Reading Theory or Trans-active

Reading is a social process where there are interaction between reader and content of a text or writing, therefore subtly exists an interaction between reader and writer of a book.

It can be concluded based on the bottom up theory, reading a letter is a basic step in understanding a reading text.

Tarigan[6] divides important aspects of reading into these guide lines:

1. Mechanical Skills, which is considered in the lower order. This aspect covers:

a. Identifying letter form.

b. Identifying linguistic parts (phoneme, word, phrase, clause pattern, sentence, etc)

c. Identifying relation or correspondence of spelling and sound pattern.

d. Low level of reading speed.

2. Comprehension skills, which is considered in the higher order. This aspect covers:

a. Comprehend meaning definition.

b. Comprehend meaning.

c. Evaluation or assessment (content, form)

d. Flexible reading speed, that adjustable to particular situation.

From both important reading aspects in reading, it can be inferred that reading letter is in the early introduction of mechanical skills, which takes place before one do comprehension skills.

\section{Katakana Letters}

Katakana letters are formed from straight and sketchy lines or chokusenteki (直線的). These straight and sketchy lines that differ them from hiragana (Ang, 2005).

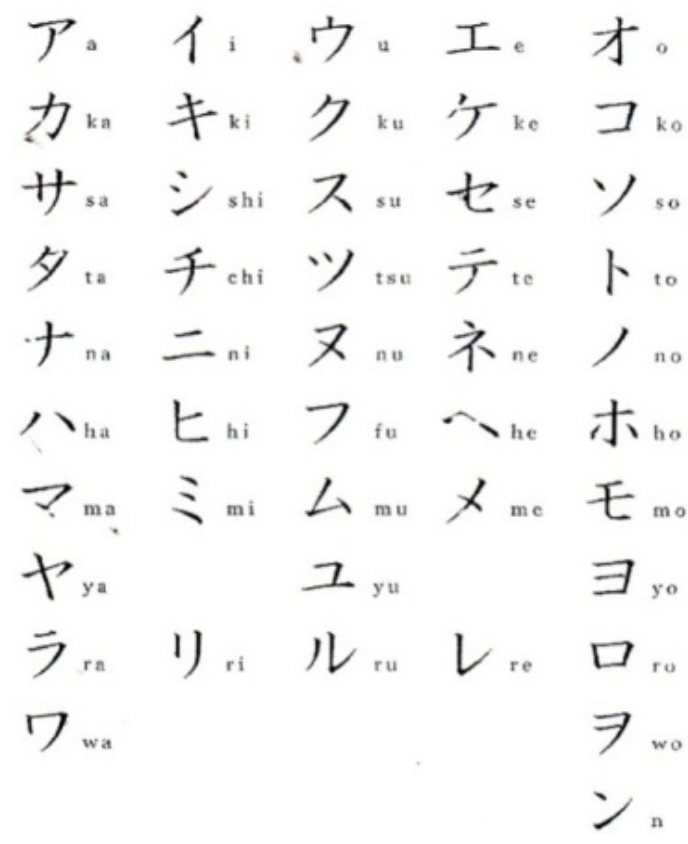

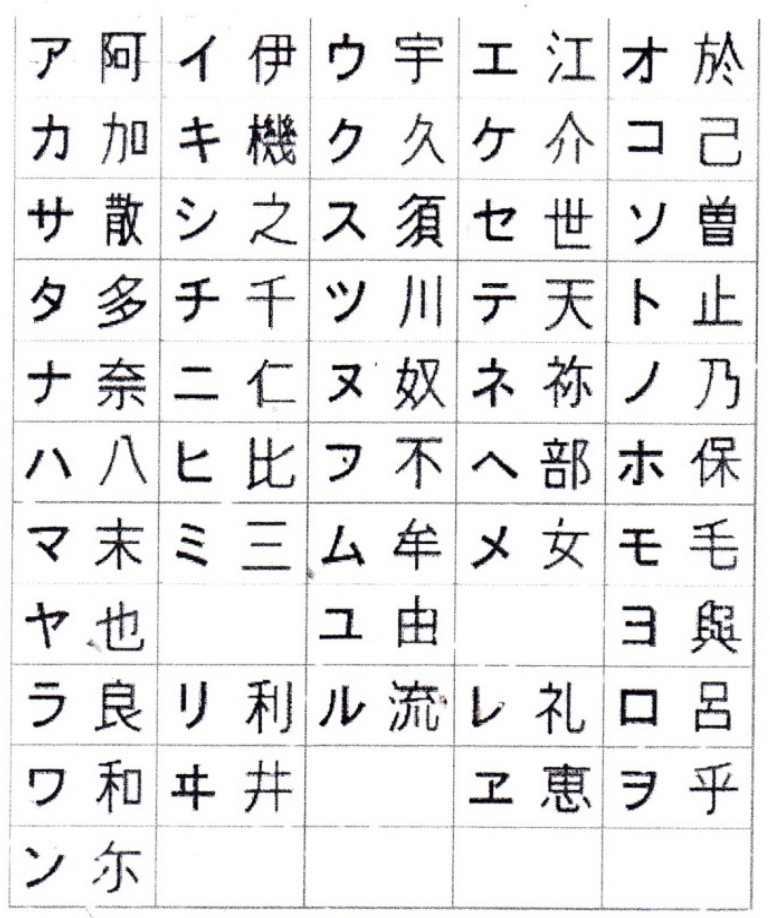

Picture 1\& 2. Katakana Letter \& Origin of Katakana Letter

The word "kata" means partial, incomplete, or separated. The word "katakana" means "kana separation", as katakana script which originated from more complicated kenji component (Japan: an Illustrated Encyclopedia, 1993).

In koujien dictionary, the function of katakana (Izuru, 1998) is stated as:

\section{現在では主に外来語や擬音語などの表記に用いる。}

"Genzai de waomonigairaigoyagiongonado no hyoukinimochiiru", Which means in the contemporary time, generally katakana letter is used for foreign language writing and onomatope.

Although katakana and hiragana letters are in the group of kana letter, but the function is different. Katakana letter is used in the writing of Japanese words which comes from absorption of foreign language, foreign country, animals, foreigner's name, plants, and foreign cities (Ang, 2005).

In modern Japanese, katakana is frequently used for transcriptions of foreign words except China (gairaigo). Example; "television" is written terebi. And also, katakana is used for name of country, foreign spots, and foreigner's name. For example, USA is written as America (テレビ) .not in the kanjiateji's spelling (亜米利加).

Katakana is also used in onomatope (words that describe sounds) for instance; pinpon, (ピンポン), which means "ding-dong" (bell sound).

Technical terms and science, like animal species' names, plants, and minerals also often written in katakana. Homo sapiens (ホモサピエンス, sebagai spesies, is written hito ( $\mathrm{t}$ h), not the Kanji version (A).

Katakana also often (not always) used for transcription of Japanese company, e.g: Suzuki becomes スズキ, and Toyota 
becomes トヨ夕. Katakana also serves as reinforcement, especially on signs, advertising and billboard. For example, seems common to see koko コ(here), gomi ゴミ(waste), ormegane メガネ (glasses). Reinforcement using katakana in sentences is also sometimes done by scientific writers.

Katakana also to show on'yomi (speech that comes from Chinese) from kanji in dictionary, kanji h has Japanese utterance written in hiragana as hito ひと (human), and utterance from China, written in katakana jin ジン (to show group of people).

Katakana sometimes serves as hiragana replacer or as furigana to give utterance a word that is written in Latin letter, or for foreign word, which is written in Kanji for meaning, kanji but meant to be read as the origin form.

Katakana sometimes also used to indicate words that speech in foreign accent or unusual, in foreign character, robot, etc. For example, in manga, foreign character speech or robot can be represented by konnichiwa コンニチワ (hello) not hiragana which is more typical こんにちは.

\section{Critical Framework}

Since it is important to improve katakana reading comprehension of grade ten students of SMK, and the benefit of using association picture media is to ease students in memorizing the shape of katakana letter in a long term, then it is assumed that association picture media is suitable to be implemented in the learning process of katakana letter. So, it can be inferred that association picture media is effective to improve katakana letter reading comprehension.

\section{Method and Sampling}

This research applied quantitative approach by way of experiment quation method. Sampling was conducted by technique of cluster sampling. Two classes of gradeten students of SMK Manajemen Jakarta are determined as experiment and control classes.

Class AK of grade $\mathrm{x}$ wass determined as experiment class, a class which was exposed by association picture media in the teaching of katakana letter, and class TN was determined as control class, a class which wasn't exposed by association picture media in the teaching of katakana letter. The data collected by using an instrument in a form of a test to measure the comprehension in reading katana letter.

\section{Finding and Discussion}

The research shows the end result of the comprehension of students in reading katana letter as follow:
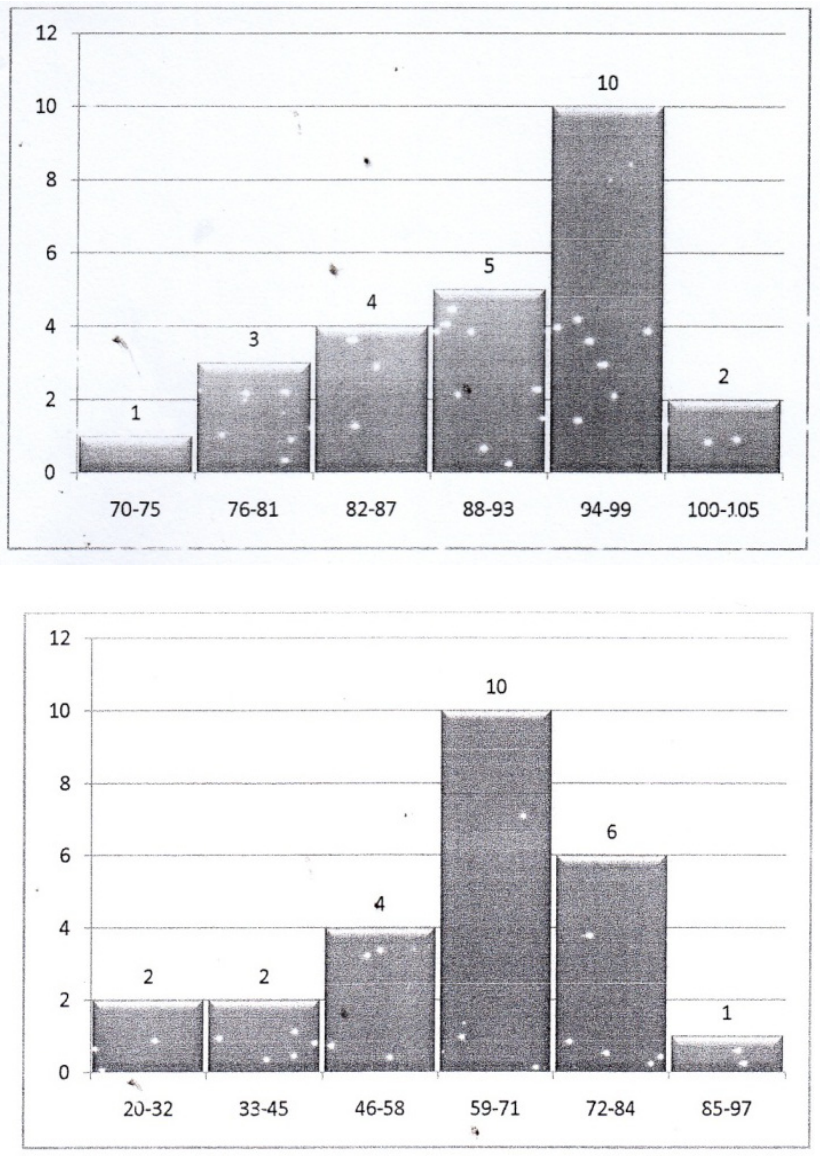

Picture 3 \& 4. Experiment \& Control Class Scores

Picture 4 shows that the score of the comprehension of reading katana letter of the control class, from 10 students the scores are in the range of 59-71, the highest score is 97 , and the average score is 61,2 .

Looking at the test result the comprehension of reading katana letter of experiment class and control class, it is revealed that the average score of experiment class is higher than that of the control class.

After a comparative test conducted using t-test, it showed that $\mathrm{t}$ count $=7,67 \geq 1,67=\mathrm{t}$ table with the level of significant 0,05 , it was assumed that the comprehension of reading katana letter from students who were exposed with association picture media was better than those who weren't.

The followings are the result of questionnaire done by experiment class students. The questionnaire contains questions concerning of the association picture media application in katakana letter reading class. 
1. Students like Japanese class

Table 1.

\begin{tabular}{|c|c|c|c|}
\hline No. & Option & F & $\%$ \\
\hline & Like a lot & 7 & 28 \\
\hline & Like & 18 & 72 \\
\hline & Doesn't like much & 0 & 0 \\
\hline & Doesn't like at all & 0 & 0 \\
\hline \multicolumn{2}{|c|}{ Total } & 25 & 100 \\
\hline
\end{tabular}

2. Students think Japanese letter interesting

Table 2

\begin{tabular}{|c|c|c|c|}
\hline No. & Option & $\mathrm{F}$ & $\%$ \\
\hline & Very interesting & 9 & 36 \\
\hline & Interesting & 16 & 64 \\
\hline & Not too interesting & 0 & 0 \\
\hline & Not interesting at all & 0 & 0 \\
\hline & Total & 25 & 100 \\
\hline
\end{tabular}

3. Students were interested in learning katakana letter.

Table 3

\begin{tabular}{|c|c|c|c|}
\hline No. & Option & $\mathrm{F}$ & $\%$ \\
\hline 1 & Very interested & 5 & 20 \\
\hline 2 & Interested & 18 & 72 \\
\hline 3 & Not too interested & 2 & 8 \\
\hline 4 & Not intereted at all & 0 & 0 \\
\hline \multicolumn{2}{|r|}{ Total } & 25 & 100 \\
\hline
\end{tabular}

4. Students found katakana letter difficult.

Table 4

\begin{tabular}{|c|c|c|c|}
\hline No. & Option & $\mathrm{F}$ & $\%$ \\
\hline 1 & Very difficult & 2 & 8 \\
\hline 2 & Difficult & 14 & 56 \\
\hline 3 & Not too difficult & 9 & 36 \\
\hline 4 & Not difficult at all & 0 & 0 \\
\hline \multicolumn{2}{|r|}{ Total } & 25 & 100 \\
\hline
\end{tabular}

5. Students found katakana letter is important.

Table 5

\begin{tabular}{|c|c|c|c|}
\hline No. & Option & $\mathrm{F}$ & $\%$ \\
\hline 1 & Very important & 9 & 36 \\
\hline 2 & Important & 16 & 64 \\
\hline 3 & Not too important & 0 & 0 \\
\hline 4 & Not important at all & 0 & 0 \\
\hline \multicolumn{2}{|r|}{ Total } & 25 & 100 \\
\hline
\end{tabular}

6. Students were interested in katakana letter class that apply the media.

Table 6

\begin{tabular}{|c|c|c|c|}
\hline No. & Option & $\mathrm{F}$ & $\%$ \\
\hline 1 & Very interseted & 18 & 72 \\
\hline 2 & Interseted & 7 & 28 \\
\hline 3 & Not too interseted & 0 & 0 \\
\hline 4 & Not interseted at all & 0 & 0 \\
\hline \multicolumn{2}{|r|}{ Total } & 25 & 100 \\
\hline
\end{tabular}

7. Students found katakana letter class that application of association picture media helpful to comprehend katakana letter.

Table 7

\begin{tabular}{|c|c|c|c|}
\hline No. & Option & $\mathrm{F}$ & $\%$ \\
\hline 1 & Very helpful & 20 & 80 \\
\hline 2 & Helpful & 5 & 20 \\
\hline 3 & Not too helpful & 0 & 0 \\
\hline 4 & Not helpful at all & 0 & 0 \\
\hline \multicolumn{2}{|r|}{ Total } & 25 & 100 \\
\hline
\end{tabular}

8. Students found katakana letter class that apply association picture media is motivating to comprehend katakana letter.

Table 8

\begin{tabular}{|c|c|c|c|}
\hline No. & Option & $\mathrm{F}$ & $\%$ \\
\hline 1 & Very motivating & 13 & 52 \\
\hline 2 & Motivating & 12 & 48 \\
\hline 3 & Not too motivating & 0 & 0 \\
\hline 4 & Not motivating at all & 0 & 0 \\
\hline \multicolumn{2}{|r|}{ Total } & 25 & 100 \\
\hline
\end{tabular}

9. Students found katakana letter class that applies association picture media is interesting.

Table 9

\begin{tabular}{|c|c|c|c|}
\hline No. & Option & $\mathrm{F}$ & $\%$ \\
\hline 1 & Very interesting & 17 & 68 \\
\hline 2 & Interesting & 8 & 32 \\
\hline 3 & Not too interesting & 0 & 0 \\
\hline 4 & Not interesting at all & 0 & 0 \\
\hline \multicolumn{2}{|r|}{ Total } & 25 & 100 \\
\hline
\end{tabular}

10. Students found katakana letter class that application association picture media interrupted concentration.

Table 10

\begin{tabular}{|r|c|c|c|}
\hline No. & Option & F & $\%$ \\
\hline 1 & Very interrupting & 0 & 0 \\
\hline 2 & interrupting & 0 & 0 \\
\hline 3 & Not too interrupting & 7 & 28 \\
\hline 4 & Not interrupting at all & 18 & 72 \\
\hline \multicolumn{2}{|r|}{ Total } & 25 & 100 \\
\hline
\end{tabular}


11. Students found katakana letter class that uses association picture media improved comprehension in reading katakana letter.

Table 11

\begin{tabular}{|c|c|c|c|}
\hline No. & Option & $\mathrm{F}$ & $\%$ \\
\hline 1 & Very improving & 9 & 36 \\
\hline 2 & Improving & 16 & 64 \\
\hline 3 & Not too improving & 0 & 0 \\
\hline 4 & Not important at all & 0 & 0 \\
\hline & Total & 25 & 100 \\
\hline
\end{tabular}

12. Students found katakana letter class that apply association picture media is fun.

Table 12

\begin{tabular}{|c|c|c|c|}
\hline No. & Option & $\mathrm{F}$ & $\%$ \\
\hline 1 & Very fun & 16 & 64 \\
\hline 2 & Fun & 9 & 36 \\
\hline 3 & Not too fun & 0 & 0 \\
\hline 4 & Not fun at all & 0 & 0 \\
\hline \multicolumn{2}{|c|}{ Total } & 25 & 100 \\
\hline
\end{tabular}

13. Students agreed if katakana letter class that apply association picture media becomes alternative method in katakana letter teaching.

Table 13

\begin{tabular}{|c|c|c|c|}
\hline No. & Option & $\mathrm{F}$ & $\%$ \\
\hline 1 & Very possible & 18 & 72 \\
\hline 2 & Possible & 7 & 28 \\
\hline 3 & Not too possible & 0 & 0 \\
\hline 4 & Not possible at all & 0 & 0 \\
\hline & Total & 25 & 100 \\
\hline
\end{tabular}

14. Students found katakana letter class that applies association picture media stimulated imagination in reading katakana letter.

Table 14

\begin{tabular}{|r|c|c|c|}
\hline \multicolumn{1}{|c|}{ No. } & Option & F & $\%$ \\
\hline 1 & Very stimulating & 15 & 60 \\
\hline 2 & Stimulating & 10 & 40 \\
\hline 3 & Not stimulating at all & 0 & 0 \\
\hline \multicolumn{2}{|r|}{ Total } & 25 & 100 \\
\hline
\end{tabular}

15. Students found that the class that apply association picture media eases in katakana letter reading.

Table 15

\begin{tabular}{|c|c|c|c|}
\hline No. & Option & $\mathrm{F}$ & $\%$ \\
\hline 1 & Very easy & 14 & 56 \\
\hline 2 & Easy & 11 & 44 \\
\hline 3 & Not too easy & 0 & 0 \\
\hline 4 & Not easy at all & 0 & 0 \\
\hline \multicolumn{2}{|r|}{ Total } & 25 & 100 \\
\hline
\end{tabular}

16. By using association picture media, students find it easy to read katakana letter.

Table 16

\begin{tabular}{|c|c|c|c|}
\hline No. & Option & $\mathrm{F}$ & $\%$ \\
\hline 1 & Very easy & 14 & 56 \\
\hline 2 & Easy & 11 & 44 \\
\hline 3 & Not too easy & 0 & 0 \\
\hline 4 & Not easy at all & 0 & 0 \\
\hline \multicolumn{2}{|r|}{ Total } & 25 & 100 \\
\hline
\end{tabular}

17. By using association picture media, students' activity in reading katakana letter is increased.

Table 17

\begin{tabular}{|r|c|c|c|}
\hline No. & Option & F & $\%$ \\
\hline 1 & Very active & 7 & 28 \\
\hline 2 & Active & 0 & 0 \\
\hline 3 & Not too active & 0 & 0 \\
\hline 4 & Not active at all & 0 & 0 \\
\hline \multicolumn{2}{|r|}{} & 25 & 100 \\
\hline
\end{tabular}

18. Students followed katakana letter class that applies association picture media well.

Table 18

\begin{tabular}{|c|c|c|c|}
\hline No. & Option & $\mathrm{F}$ & $\%$ \\
\hline 1 & Very well & 8 & 32 \\
\hline 2 & Well & 17 & 68 \\
\hline 3 & Not too well & 0 & 0 \\
\hline 4 & Not well at all & 0 & 0 \\
\hline \multicolumn{2}{|r|}{ Total } & 25 & 100 \\
\hline
\end{tabular}

19. Students found it difficult to read katakana letter if the class doesn't apply association picture media.

Table 19

\begin{tabular}{|r|c|c|c|}
\hline No. & Option & F & $\%$ \\
\hline 1 & Very difficult & 8 & 32 \\
\hline 2 & difficult & 12 & 48 \\
\hline 3 & Not too difficult & 5 & 20 \\
\hline 4 & Not difficult at all & 0 & 0 \\
\hline \multicolumn{2}{|c|}{ Total } & 25 & 100 \\
\hline
\end{tabular}


20. By using association picture media, difficulties in reading katakana letter can be solved.

Table 20

\begin{tabular}{|c|c|c|c|}
\hline $\begin{array}{c}\text { N } \\
\text { o. }\end{array}$ & Option & F & $\%$ \\
\hline 1 & Very solvable & 9 & 36 \\
\hline 2 & solvable & 15 & 64 \\
\hline 3 & Not too solvable & 0 & 0 \\
\hline 4 & Not solvable at all & 0 & 0 \\
\hline \multicolumn{2}{|r|}{ Total } & 25 & 100 \\
\hline
\end{tabular}

\section{Conclusions}

Based on the research of data analysis evaluation and all data that the writer received for this research, a conclusion was made that applying educational media in learning process of Japanese will help to reach learning goals, since one of the benefits of using educational media is to make learning easy.

In this research association picture media is assumed to be effective to improve students' comprehension of reading katakana letter. The special feature of association picture media that presents pictures that resembles and inter-relates katakana letters eased student to memorize katakana letter. Besides that, using association picture media, learning process becomes less boring since the students were exposed with attractive pictures and allow only little explanation verbally.

"Katakana"




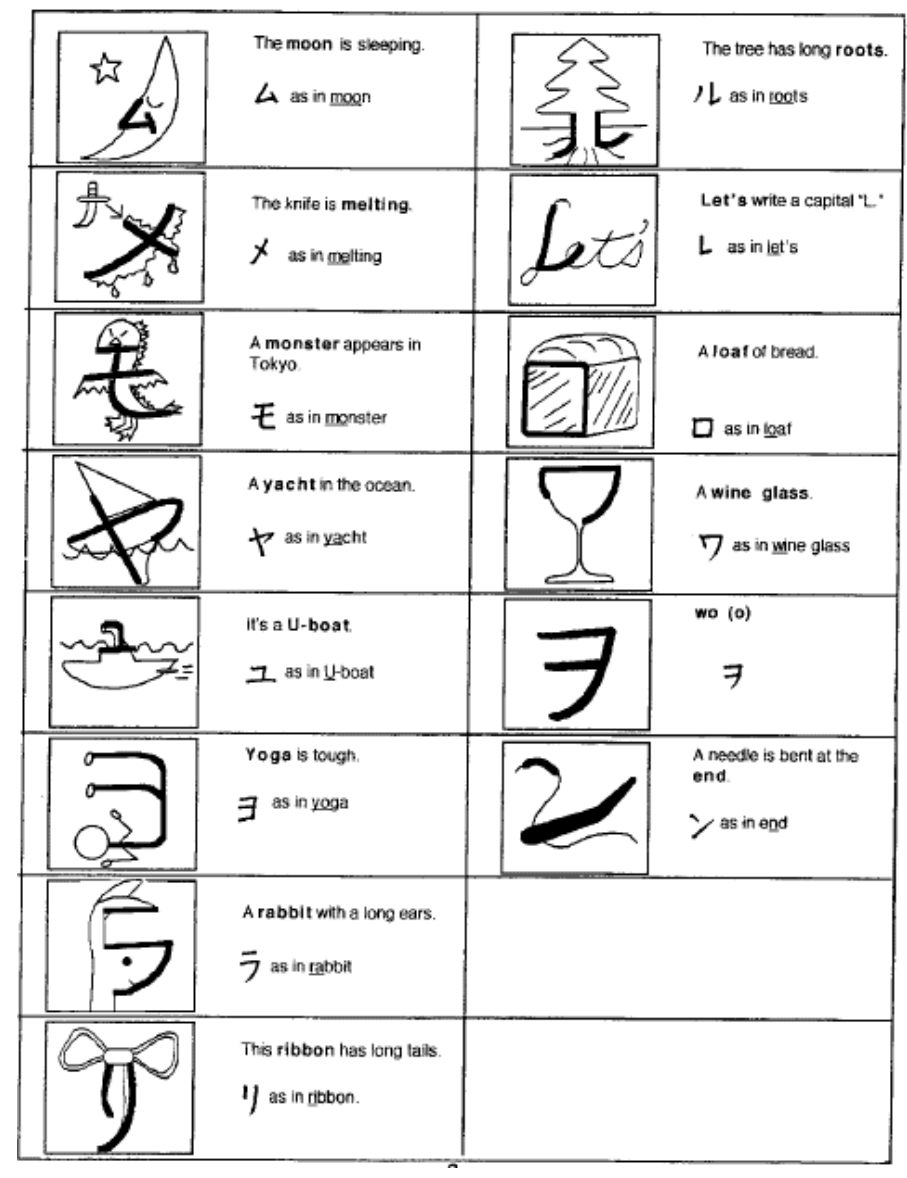

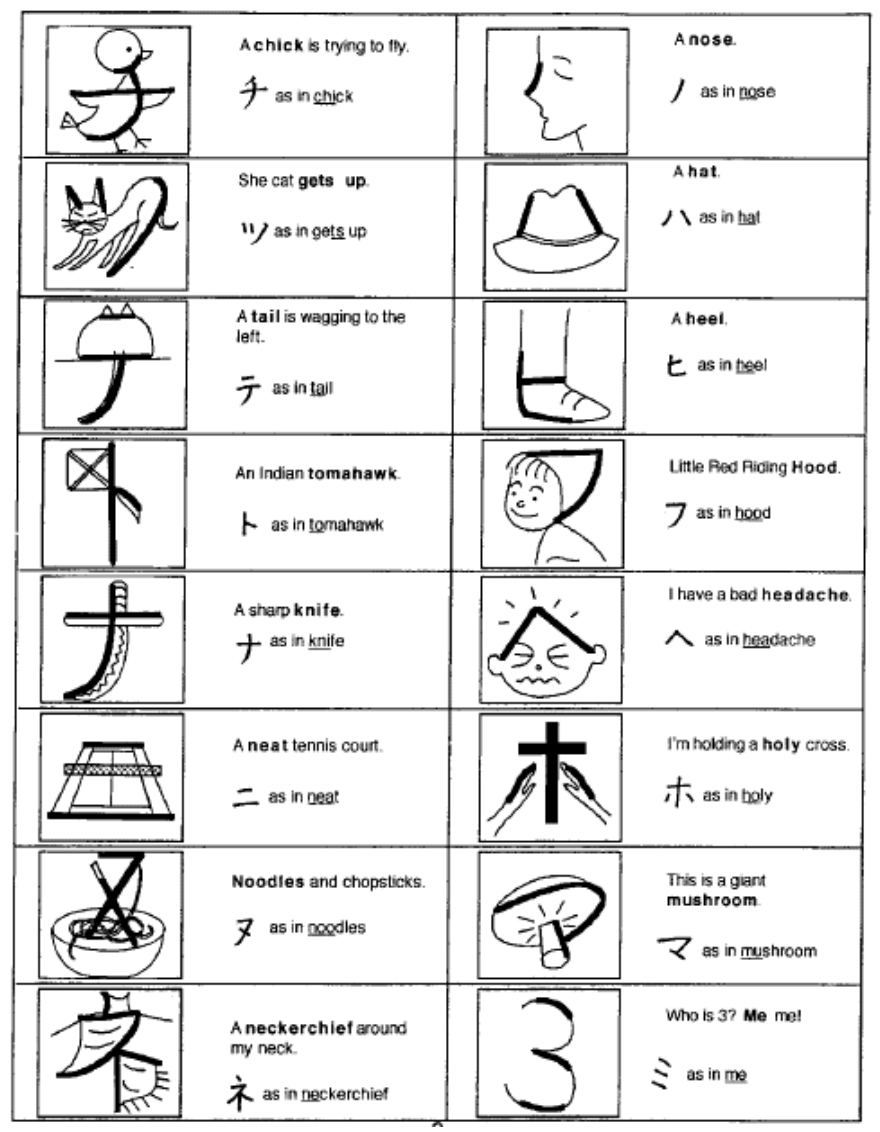




\section{REFERENCES}

[1] All, Muhammmad. Proses Kependidikan Prosedur Dan Strategi, Angkasa, Bandung. 1987.

[2] MengenalAksaraJepang (Hiragana, Katakana, Kanji), ;cetakanpertama, Puspa Swara, Jakarta. 2005.

[3] Arsyad, Azhar. Media pembelajaran. PT Raja GrafindoPersada, Jakarta, 2003.

[4] Danasasmita, Wawan. Metodologi Pembelajaran Bahasa Jepang; cetakan pertama, Rizqi Press, Bandung, 2009.

[5] Emzir. Metode PenelitianPendidikan: Kuantitatif dan Kualitatif, PT Raja Grafindo Persada, Jakarta, 2008.

[6] Frederic, Louis (Translated by $\mathrm{Ka}$ The Roth). Japan Encyclopedia, The Belkmap Press of Harvard University Press, England, 2002.

[7] Hamalik, Oemar. Media Pendidikan,PT Alumni, Bandung, 1986.

[8] Izuru, Shimura. / $\mathrm{Si}^{\wedge} 1 \mathrm{E} ; \mathrm{J}^{\wedge} \mathrm{jEJiS}$, Iwanami Shoten, Japan, 1998.

[9] Pusat Pembinaan Bahasa Departemen Pendidikan dan Budaya. Kamus Besar Bahasa Indonesia; edisi kedua, Balai Pustaka, Jakarta, 1995.

[10] Rohani, Ahmad. Media Instruksional Edukatif; cetakan pertama, PT RINEKA CIPTA, Jakarta, 1997.

[11] Roshidi, Abdul Wahab. Media Pembelajaran Bahasa Arab. UIN-Malang Press, Malang, 2009.

[12] Sudjianto dan Ahmad Dahidi. Pengantar Linguistik Bahasa Jepang; cetakan kedua, Kesaint Blanc, Bekasi, 2007.

[13] Sadiman, Arief S, dkk. Media Pendidikan (Pengertian, Pengembangan dan Pemanfaatannya), CV Rajawali, Jakarta, 1990.

[14] Sadiman, Arif S, dkk. Media Pendidikan: Pengertian, Pengembangan dan Pemanfaatannya, Rajawali Pers, Jakarta, 2009.

[15] Sameto, Hudoro. Kiat Menguasai Bahasa Asing; cetakan pertama, PuspaSwara, Jakarta, 2003.

[16] Sukardi. Metcdologi Penelitian Pendidikan (Kompetensi danPraktiknya), PT Bumi Aksara, Jakarta, 2003.

[17] Tim Penyusun Kamus Pusat Bahasa. Kamus Besar Bahasa Indonesia; edisi ketiga, Balai Pustaka, Jakarta, 2005.

[18] Usman, M. Basyiruddindkk. Media Pembelajaran; cetakan pertama, Ciputat Pers, Jakarta, 2002.

[19] Wiryawan, Sri Anitah, dkk. Strategi Belajar Mengajar Bahasa Indonesia; cetakan pertama, Karunika, Jakarta, 1987.

[20] Yudhi, Munadi. Bahan Ajar Media Pembelajaran, PSWUIN Syarif Hidayatullah Jakarta, Jakarta, 2007.

[21] Japan; an Illustrated Encyclopedia.Tokyo: kodansha Ltd, Tokyo, 1993. 